\title{
CYTOLOGICAL STUDIES OF FIVE INTERSPECIFIC HYBRIDS OF CREPIS LEONTODONTOIDES
}

PRISCILLA AVERY 
University of Californla Publications in Agricultural Sciences Volume 6, No. 5, pp. 135-167, 18 figures in text

Issued December 10, 1930

\author{
University of California Press \\ Berkeley, California
}

Cambridge University Press

London, ENGLAND 


\section{CY'TOLOGICAL STUDIES OF \\ FIVE INTERSPECIFIC HYBRIDS OF \\ CREPIS LEONTODONTOIDES}

BY

PRISCILLA AVERY

\section{INTRODUC'TION}

Cytological investigations in Crepis have been primarily concerned with the somatic chromosomes, their low number and well marked individuality being particularly favorable for such studies. Less extensive investigations have been carried on in regard to meiotic phenomena in interspecific hybrids by Collins and Mann (1923), Navashin (1927), Babcock and Clausen (1929), and Hollingshead (1930a). The study of this phase of the chromosome cycle involves greater difficulties than that of the somatic and must often be inferior on the quantitative side to similar studies in other more easily handled genera. Nevertheless, certain apparently significant facts are very strikingly demonstrated in the meiotic as well as the somatic divisions of the lyybrids of low-chromosomed species. It is therefore in illustration of these facts that the present account is given of cytological observations on five $F_{1}$ hybrids in which a single species, Crepis leontodontoides, served as one parent in the cross.

It is a pleasure to acknowledge my indebtedness to Professor E. B. Babcock for advice and interest as well as for facilities which made possible the studies reported here. I am also indebted to $\mathrm{Mr}$. C. W. Haney for three of the hybrids used in these investigations.

\section{Material, and Methods}

Two accessions (1682 and 1807) of seed from Italy were the source of the $C$. leontodontoides plants used in securing the hybrids concerned in the present study. The plants of the other species used were those belonging to strains grown in pure line in the Genetics gardens at the University of California $(C$. tectorum, 1498 and 1622 ; C. capillaris X-strain; C. parviflora, 1533; C. marschalli, 1532; C. aurea, 1636). 
Root tips from young plants were used as material for the study of somatic chromosomes. These were killed and fixed in chrom-acetic formalin according to formula 1 given by Hollingshead and Babcock (1930, p. 3), and imbedded in paraffin in the usual way. Sections were cut $8 \mu$ thick and stained with Haidenhain's iron-alum haemotoxylin.

For the study of meiotic behavior, PMC's were used, three different procedures being followed. In a few cases, and especially for tetrad counts, aceto-carmine smears of buds of the proper stage were used. Most frequently, however, the buds of approximately the right stage were fixed in Carnoy's fluid for 3-12 hours, rinsed in the higher alcohols, and stored in 70 per cent alcohol. These buds were then used for making smears with aceto-carmine as described by Hollingshead $(1930 a)$. One objection to this procedure is the large loss of PMC's in hybrids where material is apt to be scarce. In these cases some buds were fixed in chrom-acetic-formalin, or in Carnoy followed by chrom-acetic-formahin as described by Babcock and Clausen (1929). After imbedding, these buds were sectioned $10-12 \mu$ in thick'ness and stained with either haemotoxylin or gentian violet. All drawings were made from aceto-carmine smears, the sectioned material being used to supplement these in the study of meiotic behavior.

The somatic chromosomes were drawn at a magnification of 3400 and reduced one-fourth in reproduction. The meiotic phases were drawn at the same magnification (except figs. $5 a$ and $5 c, \times 3700$ ) and reduced one-half in reproduction.

\section{The Species Used in the Crosses and Their F 1 Mrbrids}

The species hybrids used in the present study were made between Crepis leontodontoides and five other Crepis species belonging to three subgenera. C. leontodontoides has been placed in the subgenus Eucrepis because it has a spongy thickened mid-rib on the inner involucral bracts, and the achenes found in some forms are beakless. Howerer, the very short beaks of the achenes in certain other forms have caused this species to be chassified under Barkhausia in several works. In fact $C$. leontodontoides is really a border-line species with reference to the three large subgenera of Crepis, for the evidence herein reported certainly indicates a derivation in common witl one or more species of Catonia. To the subgenus Eucrepis belong the species $C$. capillaris, $C$. tectorum, and $C$. parviflora, with all of which species $\mathrm{F}_{1}$ hybrids 
with $C$. leontodontoides were obtained. C. aurca is the only species of the subgenus Catonia with which hybrids were secured, although extensive crosses were made with $C$. tingitana. $\mathrm{F}_{1}$ hybrids were also secured with the Barkhausia species $C$. marschalli.

In every case the $\mathrm{F}_{1}$ hybrids possessed features characteristic of each of the two parental species. In three eases the hybrid resembled one parent more closely than the other in its gross morphology.
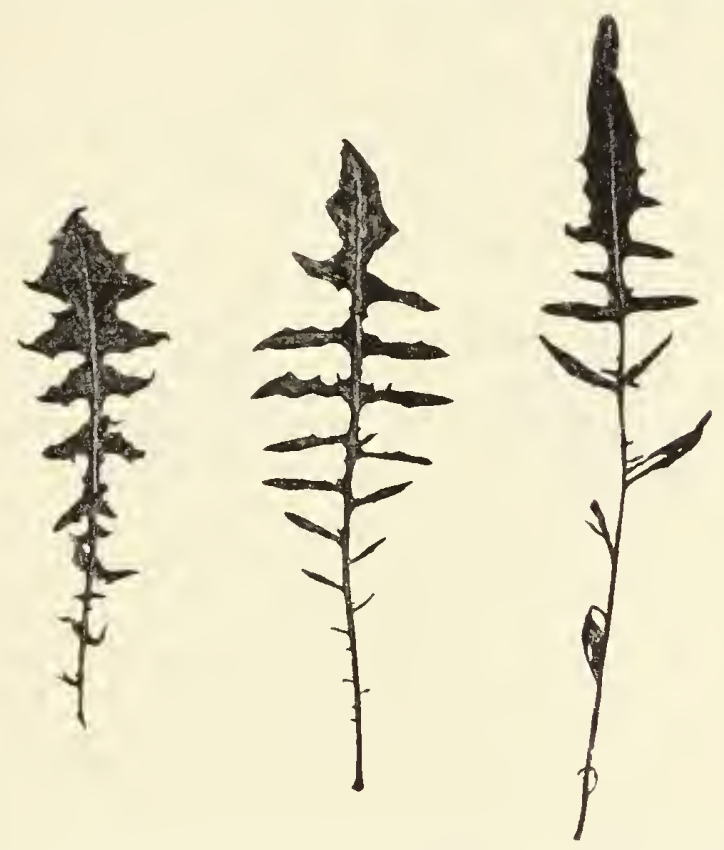

Fig. 1. Rosette leaves of Crepis leontodontoides, C. capillaris and between them their $F_{1}$ hybrid.

Thus the hybrids between leontodontoides and aurea and between leontodontoides and marschalli were closer to leontodontoides than to the other parent; while the $\mathrm{F}_{1}$ leontodontoides $\times$ parviflora resembled parviflora more closely. In the other two cases, $\mathrm{F}_{1}$ leontodontoides $\times$ capillaris and $\mathrm{F}_{1}$ leontodontoides $\times$ tectorum, the hybrid was intermediate in habit and in all character expressions. This is well shown by a comparison of the rosette leaves of $C$. leontodontoides, $C$. capitlaris and their $\mathrm{F}_{1}$ lyybrid (fig. 1).

In the $\mathrm{F}_{1}$ hybrid between $C$. leontodontoides and $C$. tcctorum a lethal Mendelian factor was operative, causing the death in the cotyledon stage of all the hybrids from four different tectorum plants, and of one-half the hybrids from two tectorum plants. In one case all 
the hybrids from one tectorum plant were viable. The genetic analysis of the same lethal factor operating in the $\mathrm{F}_{1}$ hybrid between $C$. tectorum and $C$. capillaris has been made by Hollingshead (1930b).

A summary of the vigor, fertility, and morphological characters of these $\mathrm{F}_{1}$ hybrids as determined in the present investigation has been given by Babcock and Navashin (1930, pp. 59-63). Their possible significance, in connection with the cytological evidence presented here, for the determination of phylogenetic and taxonomic relationships has also been pointed out in this report (p. 62).

The group of hybrids thus available for study possessed the haploid chromosome complement of $C$. leontodontoides in combination with five different genoms belonging to Crepis species of rarious degrees of taxonomic relationship.

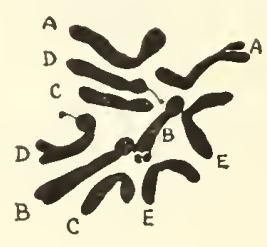

$a$

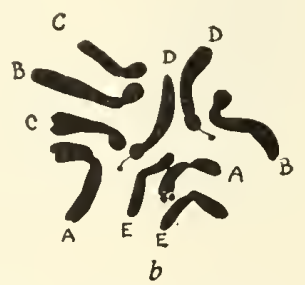

Fig. 2. Somatic metaphases of $C$. leontodontoides.

\section{The Somatic Chromosome Complement of C. Leontodontoides}

The characteristic morphology of the somatic chromosomes of $C$. leontodontoides was studied in considerable detail in order to facilitate their recognition in the chromosome complements of the hybrids, and make possible their comparison with chromosomes of other species.

In individuality the chromosomes of $C$. leontodontoides are less well marked than are those of most Crepis species with low chromosome number. This is largely due to the smaller size of the chromosomes and the lack of great differences in size within the complement: A study of many somatic plates showed, however, that each of the nembers of the five pairs can be distinguished, chiefly on the basis of the fiber attachment constriction. It was nevertheless difficult to find plates in which all ten chromosomes were in a position to show their characteristic morphologies (figs. $2 a$ and $2 b$ ).

In the leontodontoides haploid set of five, three chromosomes differ little in total length, but they may be distinguished by the point of constriction where the spindle fiber is attached. Following Navashin's schenle, a has been used to designate one of the long chromosomes 
of the set, having a submedian point of constriction about onethird of the distance from the proximal to the distal end, giving the chromosome a J-shape (fig. 2). A chromosome of about the same length, but with a subterminal constriction forming a head is designated $B$. Because of the position of the spindle fiber attachment, this chromosome often lies unbent in the plate and appears to be longer than the A-chromosome. When, however, it is bent, the B-chronrosome is very similar to the A-chromosome in appearance and may be distinguished from it only if the subterminal constriction is evident. The third of the long chromosomes is slightly shorter than the other two, and is characterized by a median constriction which typically gives a $\mathrm{V}$ shape to this E-chromosome.

The D-chromosome is intermediate in length, but is only slightly shorter than the E-chromosome. It is, however, well marked because it bears a small but distinct satellite attached by a slender thread to the proximal end of the chromosome. The constriction is subterminal, forming a small head to which the satellite is attached, but this point of constriction is often less well marked than are those of the other chromosomes. Typically, the D-chromosome lies unbent and nearly straight in the plate, but it sometimes bends at a point other than that of constriction.

The shortest c-chromosome is distinctly shorter than any of the rest. It has a submedian constriction forming arms which hold about the same relation to each other as those of the A-chromosome, i.e., $2: 1$. It is the only chromosome which can be identified from size relations alone.

\section{$\mathrm{F}_{1}$ C. leontodontoides $\times C$. tectorum \\ The Somatic Chromosomes}

None of the five chromosomes of $C$. leontodontoides resembles any of the four chromosomes of $C$. tectorum in somatic figures. The difference between the chromosomes of the two species is striking in the somatic cells of the hybrid. Here the leontodontoides chromosomes seem small in comparison to those of tectorum, and also the slight differences in length within the leontodontoides complement as compared with the greater differences in tectorum are evident (fig. 3).

The total length of the five leontodontoides chromosomes is less than three-fourths the length of the four tectorum chromosomes as measured in the same somatic cells of the hybrid. Each of the four tectorum chromosomes is easily recognized, but often the slight differ- 
ences between the leontodontoides chromosomes are not evident, especially since the D-chromosome loses its satellite in the hybrid. The D-chromosome of tcctorum retains its satellite unaltered, but in no case was a satellite found on the leontodontoides chromosome, a phenomenon (amphiplastie) which seems to be characteristic of certain interspecific hybrids as first described by Navashin (1928). Figure 3 shows a somatic plate in which the differences between the two haploid sets are evident, and each of the chromosomes from the two parents may be identified.

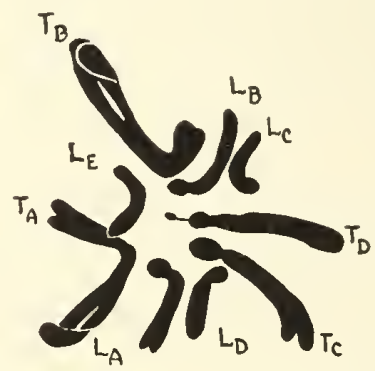

Fig. 3. Somatic metaphase of $\mathrm{F}_{1}$ C. leontodontoides-tectorum.

\section{Meiosis}

With such morphological differences between the parental chromosomes, there is little reason to expect conjugation of the chromosomes of the two species at the meiotic divisions in the hybrid. Accordingty, at diakinesis and metaphase of the first meiotic division the nine chromosomes of the hybrid are frequently umpaired. In figure $4 a$ a diakinesis stage shows nine unpaired units of which the four larger tectorum chromosomes are distinct from the five smaller and rounder leontodontoides chromosomes. Occasionally a stage immediately following the disappearance of the nuclear membrane shows the nine units arranged in a semicircular faslion, suggesting a telosynaptic arrangement (fig. $4 b$ ). Where no pairing has occurred up to diakinesis, there is apparently little tendency for the formation of a definite first metaplrase plate. Thus a scattering distribution of the nine unpailed chromosomes (fig. 4c) seems to follow directly upon such a late diakinesis as that shown in figure $4 b$. Rarely a I- II is seen in which all the nine units are rather definitely arranged in an equatorial plate, and here the four large tectorum chromosomes are distinct from the five small leontodontoides chromosomes (figs. $4 d$ and $4 e$ ). Only instances of random distribution of the unpaired chromo- 
somes to the two poles were seen, with occasional laggards which sometimes divide. It seems probable, however, that here, as in some of the other hybrids, all nine chromosomes occasionally divide in the first division, giving rise to dyads and diploid gametes. At the tetrad stage about 7 per cent dyads are present, the proportion varying from 5.2 to 8.9 per cent.
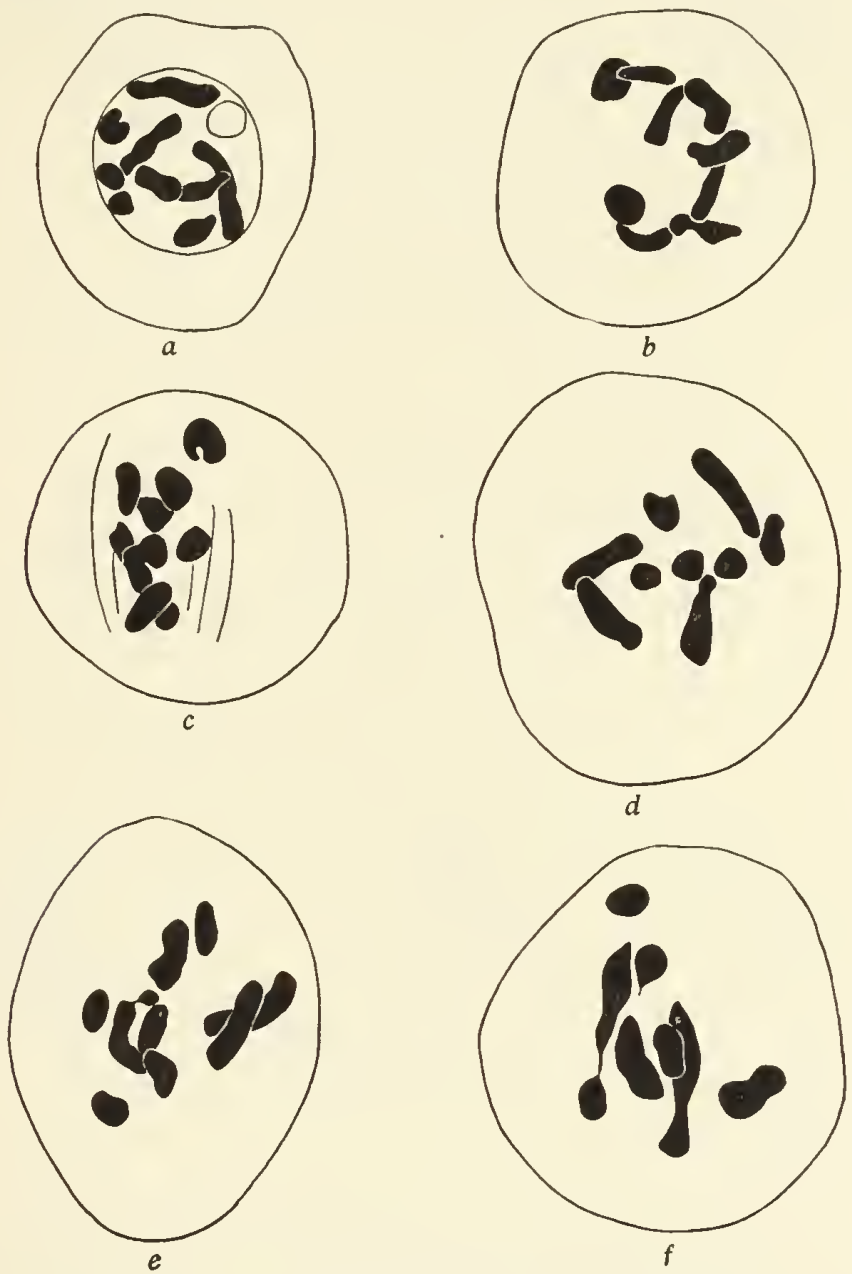

Fig. 4. Meiosis in $\mathbf{F}_{1}$ C. leontodontoides-tectorum.

$a$, diakinesis, no bivalents; $b$, early I-M, no bivalents; $c$, I-A distribution following no pairing in $\mathrm{I} ; d$, and $e, \mathrm{I}-\mathbf{M}$, no bivalents, showing four large tectorum and five smalker leontodontoides chromosomes; $f$, I-M, showing one bivalent, one loosely conjugated unequal pair, and five unpaired chromosomes.

Although the behavior of the chromosomes in meiosis just deseribed was rather frequently seen in the hybrid, it was far from being the 
characteristic behavior at the reduction division. All degrees of association between the chromosomes of the two sets were observed, from $1_{\text {II }}+7_{\text {I }}$ to $4_{\text {II }}+1_{\text {I }}$. Sometimes "loose" pairing of two chromosomes added to the irregular appearance of the first metaphase. A tabulation of 54 PMC's in diakinesis and I-M in which the number of pairs and singles was readily interpreted (table 1 ) showed that $2_{\text {II }}+5_{\text {I }}$ were most frequent, $9_{\mathrm{I}}$ and $t_{\mathrm{II}}+1_{\mathrm{I}}$ about equally frequent, and $1_{\mathrm{II}}+7_{\mathrm{I}}$ and $3_{\mathrm{II}}+3_{\mathrm{I}}$ least, although only slightly less, frequent. Examples of these types of pairing are shown in figures $4 f$ and 5 . In figure $4 f$ there is $1_{I I}+7_{I}$, with two unequal univalents showing loose association; in figure $5 a, 2_{I I}+5_{I}$; in figure $5 c$, a condition intermediate between the last two is shown, there being $1_{I I}+1$ loose $_{I I}+5_{I}$; in figure $5 b$ there are $3_{\text {II }}+3_{\text {I }}$; in figure $5 d$. a diakinesis shows $4_{\text {II }}+1_{I}$; and in figure $\bar{j} e$ a first metaphase shows $4_{\text {II }}+1_{\text {I }}$ with one pair loosely joined.

TABLE 1

Summart of Chromosome Behavior in $\mathrm{F}_{1}$ Hybrids

\begin{tabular}{|c|c|c|c|c|c|c|c|c|}
\hline \multirow{2}{*}{ F1 Hybrid } & \multicolumn{6}{|c|}{ Number of Bivalents at $\mathbf{1 - 1 \mathbf { l }}$} & \multirow{2}{*}{$\begin{array}{l}\text { Total } \\
\text { Pulc }\end{array}$} & \multirow{2}{*}{$\begin{array}{c}\text { Per } \\
\text { cent } \\
\text { tetrad } \\
\text { irregu- } \\
\text { larities }\end{array}$} \\
\hline & 0 & 1 & 2 & 3 & 4 & 5 & & \\
\hline C. leontodontoides $\mathrm{x}$ tectorum & 11 & 10 & 14 & 8 & 11 & & 54 & 7 \\
\hline 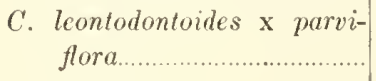 & 6 & 0 & 5 & 4 & 11 & & 26 & 7 \\
\hline 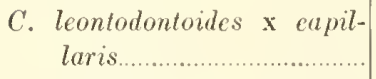 & 11 & 4 & 5 & 5 & & & 25 & 23.5 \\
\hline 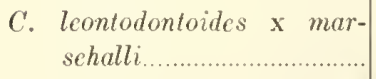 & 17 & 9 & 13 & 12 & 5 & & 56 & 20.5 \\
\hline C. leontodontoides $\mathrm{x}$ aurea.. & 0 & 0 & 0 & 2 & 12 & 39 & 53 & .7 \\
\hline
\end{tabular}

*Not including micronuclei.

The pairing is clearly between the chromosomes of the two species and not within the laploid set of either parent. Thus where there is $1_{\mathrm{II}}+7_{\mathrm{I}}$, three large tectorum and four small leontodontoides chromosomes remain unpaired (fig. $4 f$ ) ; where there are $2_{\text {II }}+5_{I}$, two large tectorum and three small leontodontoides chromosomes remain unpaired (fig. $5 a$ ) ; and with $3_{\mathrm{II}}+3_{\mathrm{I}}$, the univalents are one large tectorum and two small leontodontoides chromosomes (fig. 5b). 

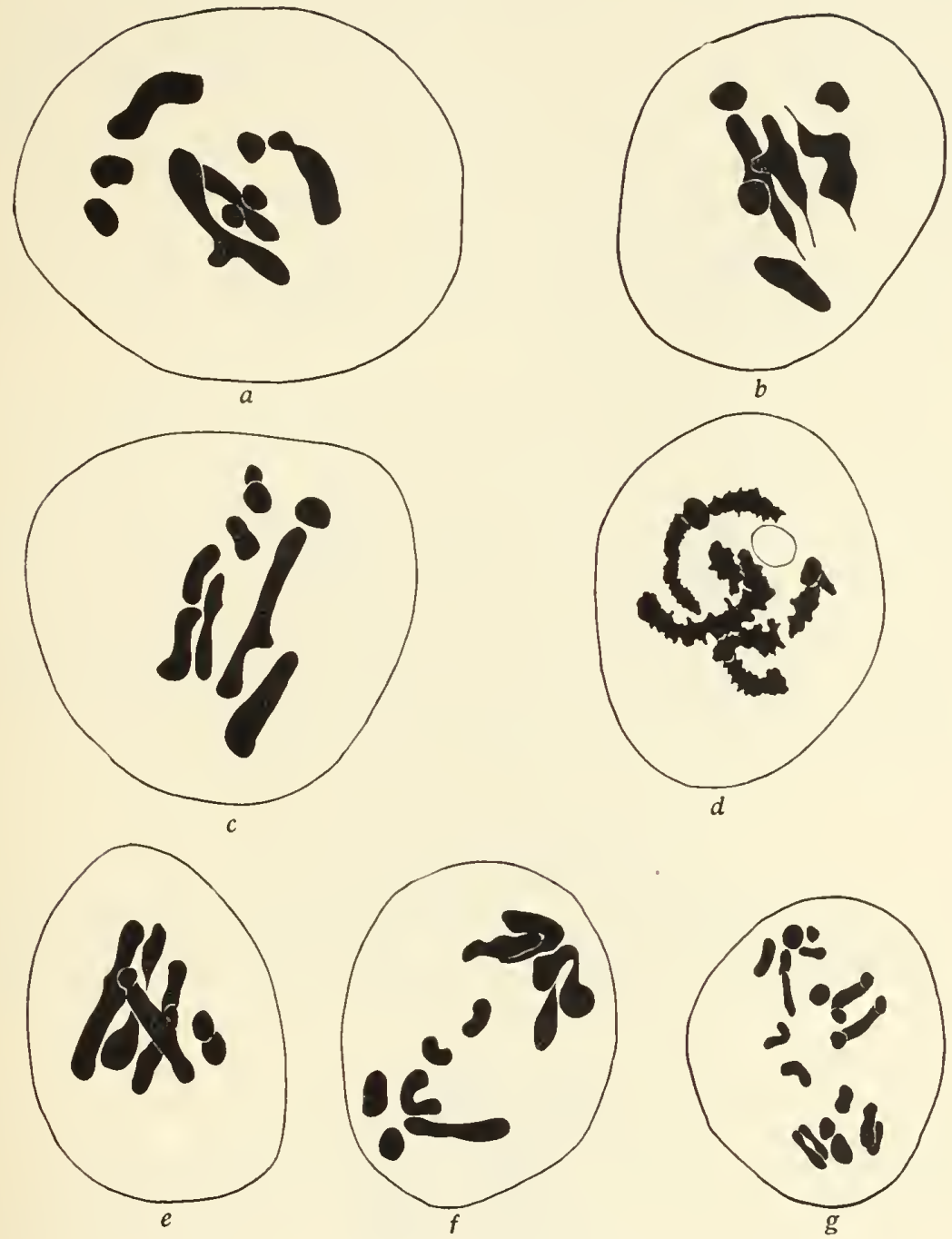

Fig. 5. Meiosis in $\mathrm{F}_{x}$ C. leontodontoides-tectorum.

$a$, I-M, with two bivalents and five univalents; $b$, I-M, with three bivalents, and three univalents; $c, \mathrm{I}-\mathrm{M}$, with one bivalent, one loose pair, and five univalents; $d$, early diakinesis and $e, \mathbf{I}-\mathbf{M}$, with four bivalents and one univalent chromosome; $f$, and $g$, late $\mathbf{I}-\boldsymbol{A}$. 
The results of such different types of behavior at I-MI are evident at I-A where the unpaired chromosomes are frequently seen to lag and divide. Thus a I-A probably following a I-M with $4_{\text {II }}+1_{I}$ is shown in figure $5 f$. Here four chromosomes are at each pole while one small leontodontoides chromosome has lagged and divided in the equatorial region. In figure $5 g$ three chromosomes are seen dividing in the equatorial region, while six halves of univalent chromosomes are at each pole. Such an anaphase probably leads to the formation of diploid or near diploid gametes, as evidenced by the presence of 7 per cent dyads at the tetrad stage. Although lagging of unpaired chromosomes is frequent, microcytes are rare at the tetrad stage. Micronuclei are, however, frequent.

The per cent of good pollen grains, filled with protoplasm and taking aceto-carmine stain, varied at different times, from plant to plant and from flower to flower. Under usual conditions, the average per cent of good grains was 5.5 varying from 3.8-10 per cent. After a period of warm weather, however, the proportion in two plants was found to be 21.3 and 23.7 per cent respectively. Even the apparently good pollen grains, however, were incapable of producing viable offspring, no progeny being obtained from the few seeds set after numerous backerossings of the hybrid with both parents.

\section{$\mathrm{F}_{1}$ C. leontodontoides $\times$ C. parviflora.}

\section{Somatic Chromosomes}

In somatic cells of the hybrid, the two longest ( $A$ and $B$ ) of the four chromosomes of the parviflora parent are distinct from all the

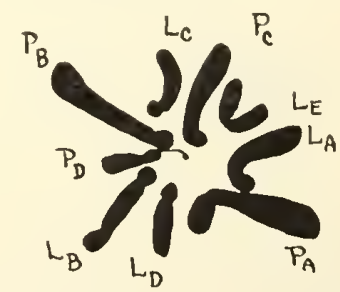

Fig. 6. Somatic metaphase of $\mathrm{F}_{1}$ C. leontodontoides - parviflora.

leontodontoides chromosomes owing to their greater length. The parviflora satellited D-chromosome, however, is shorter than any of the leontodontoides chromosomes. This is of interest in connection with its suggested origin by fragmentation from the satellited chromosome of $C$. capillaris (cf. Babcock and Navashin 1930). It retains its satel- 
lite on a long thread, and is thus easily identified. The D-chromosome of lcontodontoides loses its satellite, as in the hybrid with tectorum. The c-chromosome of parviftora is so similar to the B-chromosome of leontodontoides in morphology that distinetion between the two is not usually possible (fig. 6).
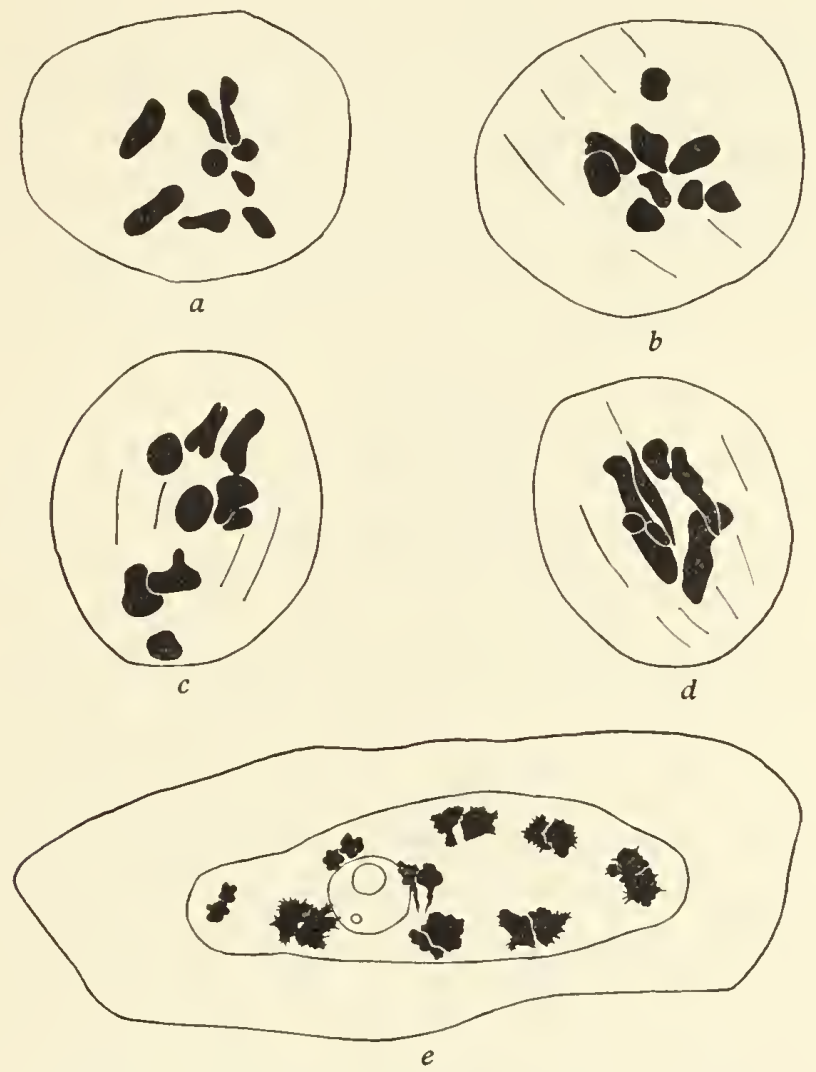

Fig. 7. Meiosis in $\mathrm{F}_{1}$ C. leontodontoides-parviflora.

$a, \mathbf{I}-\mathbf{M}$, with no bivalents; $b$, and $c, \mathrm{I}-\mathbf{A}$, showing nine univalent chromosomes; $d, \mathbf{I}-\mathbf{M}$, with four bivalents and one univalent chromosome; $e$, tapetal cell showing diakinesis-like stage.

\section{MeIOSIS}

In the meiotic divisions the distinction between the leontodontoides and parviflora chromosomes is not so great as in the hybrid with tectorum, but the behavior of the chromosomes is rather similar. The same variation in the amount of pairing occurs, but more regular pairing is more frequent. Thus at diakinesis and I-MI, $4_{\mathrm{II}}+1_{\mathrm{I}}$ are seen more frequently than in the hybrid with tectorum, but $9_{\mathrm{I}}$ are also 
rather frequent, and intermediate amounts of pairing with $1_{I I}+7_{\mathrm{I}}$, $2_{\text {II }}+5_{\mathrm{I}}$ and $3_{\mathrm{II}}+3_{\mathrm{I}}$ occur (figs. $7 a-7 d$ ). The types of pairing observed in 26 PMC's are listed in table 1.

The average per cent of dyads at the tetrad stage in the plants examined was again 7 , but the variation from plant to plant was great and that from bud to bud of the same plant only slightly less. Thus the per cent of dyads varied from .5 to $17 . \overline{7}$, the majority of counts showing 3-7 per cent. There were exceedingly few microcytes but micromuclei were frequent. A few triads and pentads were also seen.

The average proportion of good pollen grains in mature pollen was 6 per cent, but the variation was from 1-20 per cent. Flowers on a single plant showed a variation from 4-20 per cent. Most of the good pollen grains were extra large indicating that they came from dyads which probably contained a diploid complement of chromosomes.

In this hybrid a very striking example of a diakinesis-like stage in a tapetal cell was observed. Winge (1917) has found diakinesis-like stages in nuclei of the tapetum of IIumulus japonicus and other species, which he regards as "a special method of mitotic nuclear division, normally including a typical diakinesis stage, presumably due to anticipated chromosome splitting.', 'The tapetal cell observed in the present case had the size and shape of the normal tapetal cells and was much larger and more oblong than the PMC's. It was observed, however, in an aceto-carmine smear, so that its place of development is unknown. Within the large oval nucleus were nine distinct pairs of short thick chromosomes, lying close to the nuclear membrane (fig. 7e). A vacuolated nucleolus was present as at diakinesis in a PMC. The edges of the chromosomes were somewhat "fringed" as in a typical diakinesis. The fact that nine apparent pairs of chromosomes were present here suggests that a longitudinal division had taken place giving rise to apparent bivalents, the total number of chromosomes being twice that of the somatic cells of the hybrid. This corresponds closely with Winge's observations in II umulus, and no doubt here as in Humulus the diakinesis-like stage is not followed by reduction, but by further cliromosome division. 


\section{$\mathrm{F}_{1}$ C. capillaris $\times$ C. leontodontoides.}

\section{Somatic Chromosomes}

In somatic cells of the hybrid, the three chromosomes of capillaris are morphologically distinct from the leontodontoides chromosomes, all three being larger than any of the leontodontoides cluromosomes. The capillaris chromosomes maintain their individuality, the satellite always being present on the D-chromosome. However, the satellite on the D-chromosome of leontodontoides was never seen (fig. 8).

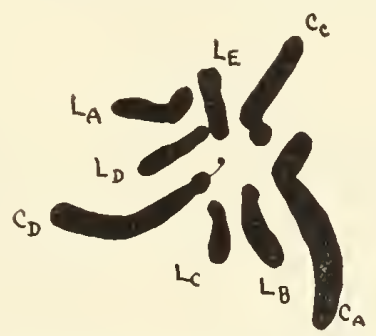

Fig. 8. Somatic metaphase of $\mathbf{F}_{1}$ C. capillaris-leontodontoides.

\section{Meiosis}

The great difference in size between the capillaris and lcontodontoides chromosomes makes it possible to distinguish the cliromosomes of the two parents in PIC's as well as in somatic tissues. Thus in figure $9 a$ three large capillaris and five smaller lcontodontoides chromosomes are seen in an early metaphase where no pairing occurred. As a rule the meiotic divisions in this hybrid are very irregular. Eight umpaired chromosomes can frequently be seen at diakinesis or early first metaphase, and only very rarely can any true pairing be found, although a loose association at I-M occasionally takes place. Thus in figure $9 b$ two typical pairs have been formed and another pair of chromosomes is loosely associated leaving two small leontodontoides chromosomes unpaired.

It is more usual to find some or all of the cliromosomes dividing in the first division, and apparently the unpaired chromosomes frequently enter a distributional anapluase in which they may divide without having formed as definite a I-M plate as that shown in figure $9 a$. Thus in figure $9 c$, a $4-4$ distribution is taking place at $\mathrm{I}-\mathrm{A}$ but 
four of the chromosomes have already divided, and the other four are in the process of division, probably resulting in an interkinesis somewhat like that in figure $9 d$. Here there was probably an $8-8$ distribution of halves of univalent chromosomes, but in one nucleus three chromosomes are again dividing and in the other nucleus one chro-
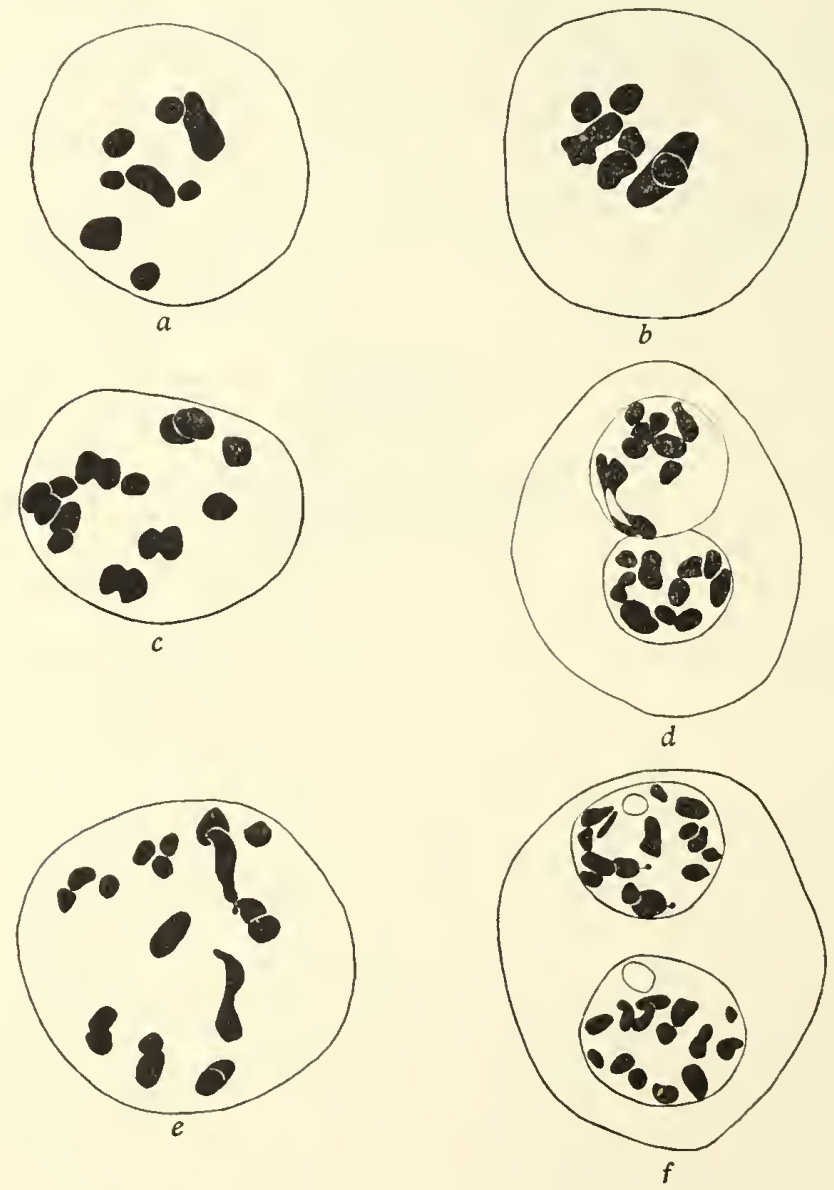

Fig. 9. Meiosis in $\mathrm{F}_{1}$ C. capillaris-leontodontoides.

$a, \mathrm{I}-\mathrm{M}$, with no pairing between the three large capillaris and five small leontodontoides chromosomes; $b$, I-M, with two bivalents, one loose pair, and two univalents; $c, \mathrm{I}-\mathrm{A} ; d$, interkinesis, showing products of double division or fragmentation; $e, \mathrm{I}-\mathrm{A}$, where fragmentation has given rise to at least 20 units; $f$, interkinesis, at least fourteen units in each nucleus.

mosome appears to be doubly dividing. In this one large chromosome both longitudinal and cross-division seem to be taking place, and many other PIIC's give evidence of fragmentation as well as early 
division of chromosomes. Thus figure $9 e$ apparently corresponds to a $\mathrm{I}-\mathrm{A}$ but division or fragmentation is giving rise to at least twenty units. That double division or fragmentation occurs in the first meiotic division is shown by the interkinesis in figure $9 f$, where at least fourteen units, some extremely small, are seen in each nucleus.
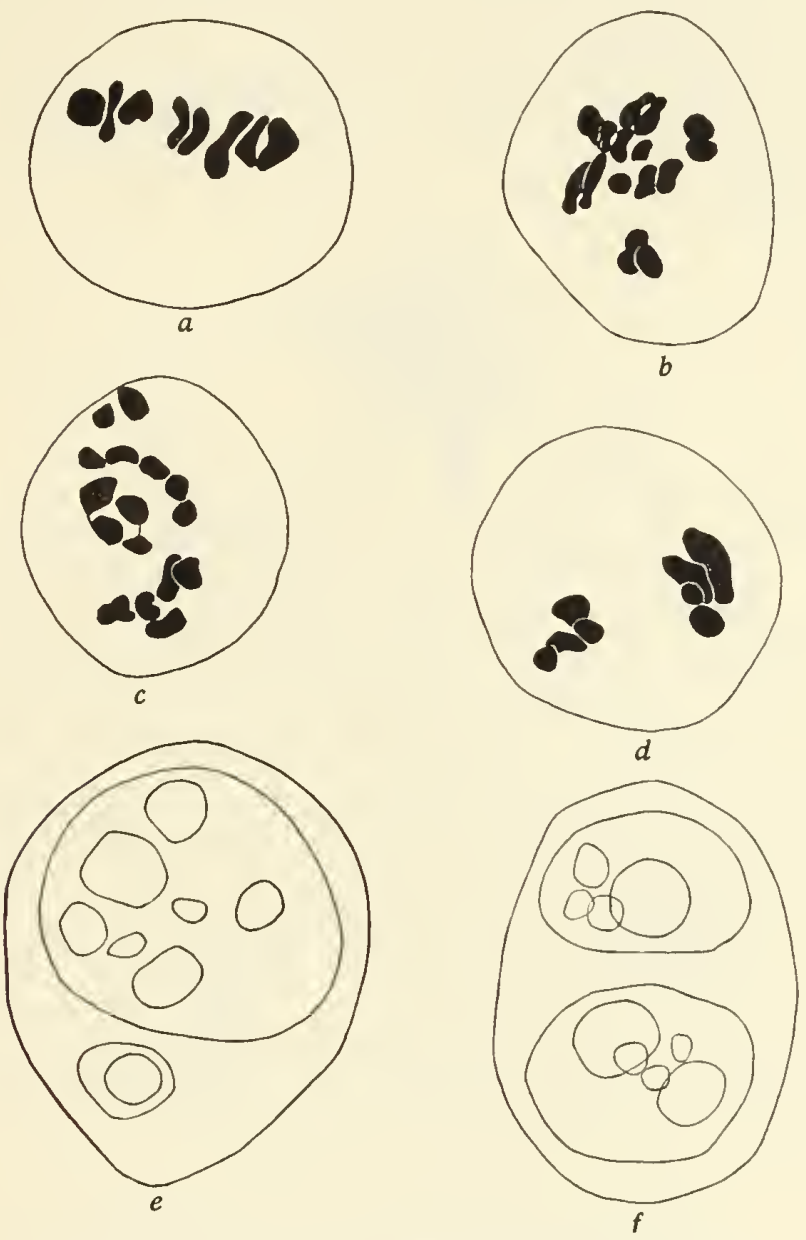

Fig. 10. Meiosis in $\mathbf{F}_{1}$ C. capillaris-leontodontoides.

$a$, I-M, eight univalent chromosomes forming an equatorial plate; $b$, late I-M, eight univalent chromosomes dividing; $c$, I-A, irregular division of chromosomes; $d$, I-T, showing $4-1$ distribution of univalent chromosomes; $e$, monad, with mierocyte, five large, and three small nuclei; $f$, dyad with three large and six small nuclei.

Occasionally a metaphase is found with the eight chromosomes forming an equatorial plate and undergoing division, as shown in. figures $10 a$ and $10 b$. Usually, however, the division seems to be 
accomplished more irregularly at various stages of $I$ as shown in figures $9 e, 9 f$ and $10 c$. The latter figure shows a $\mathrm{I}-\mathrm{A}$ where six chromosomes have already divided, five halves being at one pole, two at the other, and five in between the plates, and in addition two chromosomes are just completing their division in the equatorial region. Such irregular division leads to various numbers of chromosome umits at II-MI. Only rarely are I-T or II-T stages seen in which a total of only eight units can be identified, but the PXIC in figure $9 d$ shows a I-T with four units in each plate, no division or fragmentation having taken place.

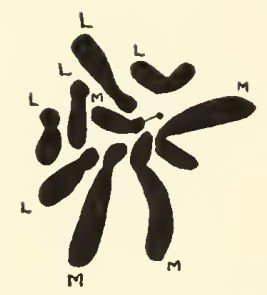

Fig. 11. Somatic metaphase of $\mathrm{F}_{1}$ C. leontodontoides-marschalli.

The irregular meiotic behavior is reflected in the tetrad stage. Micronuclei are frequent in all cells of the tetrads, and where four cells are formed there is considerable variation in their size. Dyads and triads are frequent, an average of about 22.4 per cent being counted, the variation in four buds from one plant being from 17.3 to 26.9 per cent. The dyads contain many nuclei or micro-nuclei, eight or nine usually being present. Thus in figure $10 \mathrm{e}$, a monad with a microcyte has eight nuclei of various sizes and in figure $10 f$ a dyad has three large and six small nuclei. Such behavior at meiosis can, of course, seldom lead to the formation of good pollen grains. Most of the mature pollen consists of small empty grains, and 3 per cent was the highest number of stamable grains observed.

\section{$\mathrm{F}_{1}$ C. leontodontoides $\times$ C. marschalli.}

\section{The Somatic Chromosomes}

In somatic cells of the hybrid, three of the four marschalli chromosomes are distinct from all the leontodontoides chromosomes because of their greater length. The satellited chromosome of marschalli, however, is of about the same length as the leontodontoides chromosomes. It retains its satellite and is thus to be distinguished from the leontodontoides chromosomes. The lcontodontoides satellite 
again disappears in this hybrid. In figure 11 a somatic plate from a rather old root is shown. IIere all the chromosomes are contracted so that the individuality of the leontodontoides chromosomes is not evident, but the distinction between the parental sets is obvious.
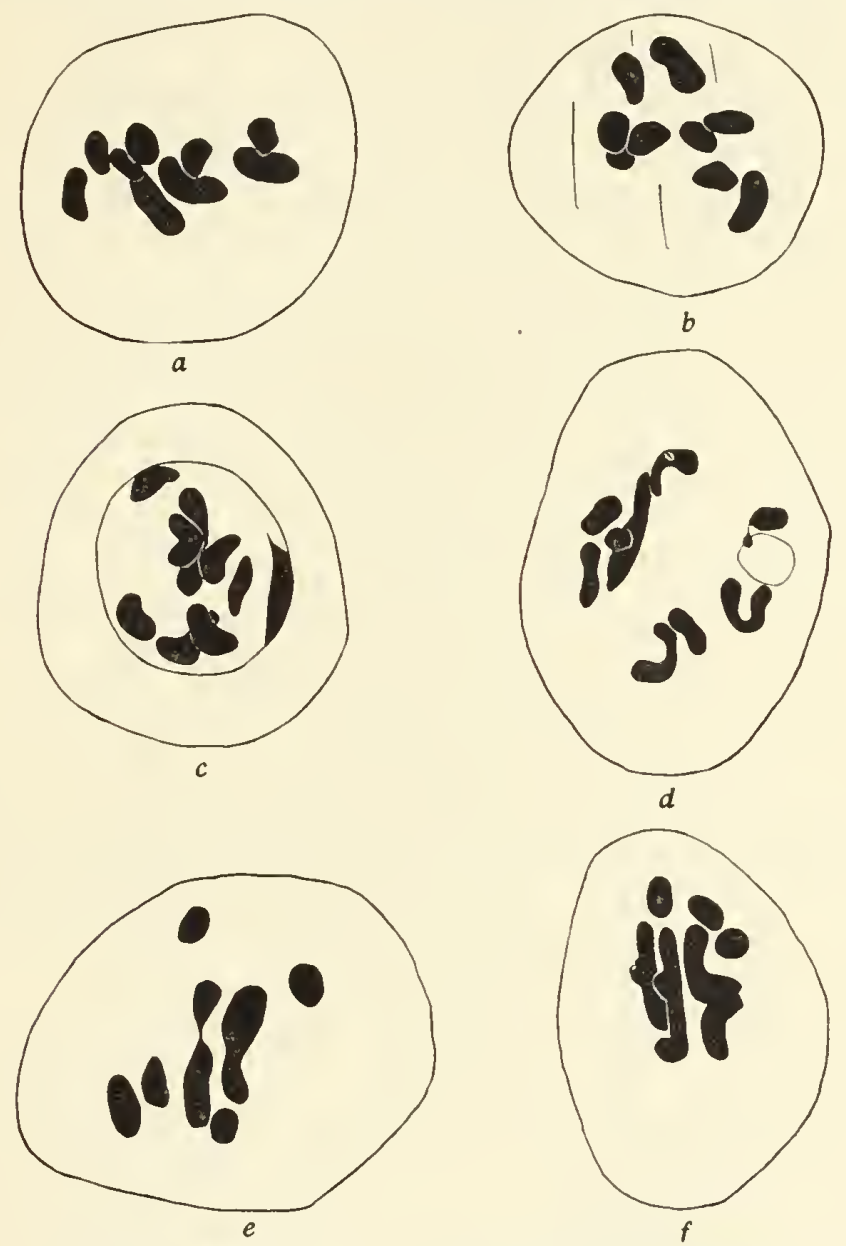

Fig. 12. Meiosis in $\mathrm{F}_{1}$ C. leontodontoides-marschalli.

a, I-M, with no bivalents, three of the marschalli chromosomes appear larger than the rest; $b, \mathbf{I}-\mathrm{A} ; c$, diakinesis with nine unpaired chromosomes; $d$, late diakinesis with one bivalent and seven univalents, one with a satellite on the nucleolus; $e$, I-M, with two bivalents; $f, \mathrm{I}-\mathrm{M}$, with three bivalents.

\section{MeIosis}

In PIIC's of the hybrid the same size relations are found, three large and six smaller units being evident at I-MI where no pairing occurs (figs. $12 a$ and 12b). No pairing of the nine chromosomes is 
the most frequent behavior at diakinesis (fig. 12c) and I-M, but here the complete range of types of pairing was observed to take place, there being little significant difference between the frequency of each type of pairing seen. Thus of 56 PMC's in which the type of pairing could be determined, there were 17 with $9_{1}$, 9 with $1_{\text {II }}+7_{\text {I }}, 13$ with $2_{\text {II }}+5_{\mathrm{I}}$, 12 with $3_{\mathrm{II}}+3_{\mathrm{I}}$, and 5 with $4_{\mathrm{II}}+1_{\mathrm{I}}$.

In figure 12d, a late diakinesis shows one pair and seven single chromosomes. A small chromosome seems to have a satellite attached which is close to the nucleolus. This is probably the marschalli satellited chromosome. Such an origin of satellites on the nucleolus has been described by Kuhn (1928) and Navashin (1927). Figure 12e shows $2_{\text {II }}+5_{\text {I }}$. One of the pairs is loosely joined, showing that the synaptic mates are in reality chromosomes quite distinct in size. In figure $12 f$, there are $3_{\text {II }}+3_{\text {I }}$. The three pairs appear to have the characteristic form of bivalents in Crepis, although one of the members of each pair is conspicuously smaller than the other. In figure $13 a$ the formation of $4_{I I}+1_{I}$ shows that the chromosomes of the two species are occasionally capable of forming normal pairs to the fullest extent possible.

An anaphase in which the three large marschalli chromosomes are distinct from the rest is shown in figure 13b. Here no division of univalents has taken place. In figure $13 \mathrm{c}$ is shown a II-A after an apparent 6-3 distribution at I-A. Five chromosomes are at each pole in one half of the cell with one delayed chromosome dividing between the plates, and two chromosomes at each pole in the other half of the cell with a chromosome dividing between.

Laggard chromosomes are frequent at I-T and II-T, and result in frequent micronuclei at the tetrad stage. A II-T with five large and two small nuclei is shown in figure $13 d$. The four cells of the tetrad are often mequal in size. Dyads are frequent and often contain microcytes which vary in size up to that of the other two cells resulting in a triad. The average per cent of dyads and triads was 20.5, ranging from 12.4 to 25.3. The average per cent of good pollen grains was 5.7, and here again most of the good grains were nuch larger than normal. 

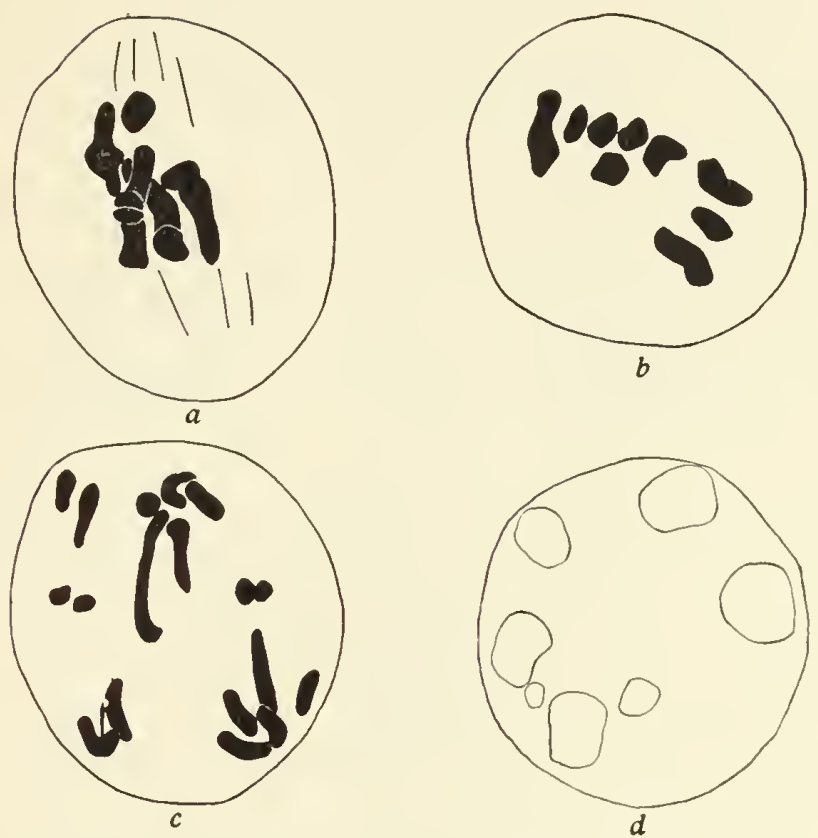

Fig. 13. Meiosis in $\mathrm{F}_{1}$ C. leontodontoides-marschalli.

$a$, I-M, with four bivalents; $b$, I-A, showing three large marschulli chromosomes; $c$, II-A, after a $6-3$ distribution at I-A; $d, I I-T$, five large and two small nuclei.
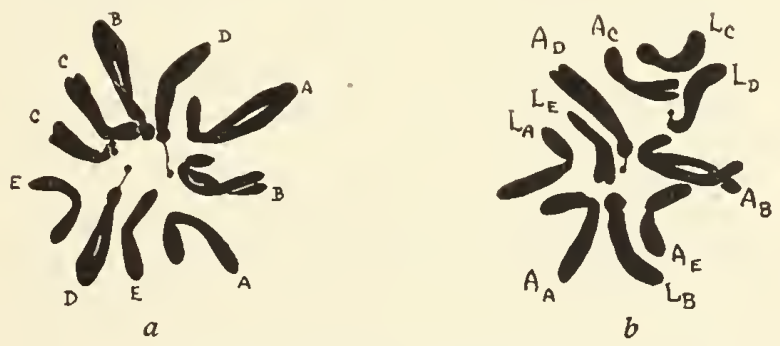

Fig. 14. Somatic metaphases.

$a$, of $C$. aurea; $b$, of $\mathrm{F}_{1} C$. leontodontoides+aurea. 


\section{$\mathrm{F}_{1}$ C. leontodontoides and C. aurea. \\ The Somatic Chromosones}

The chromosomes of $C$. aurea resemble those of leontodontoides in more than number, which is $2 \mathrm{n}=10$ in both species. The same morphological classes of chromosomes are found in aurea as in leontodontoides (fig. 14). Thus the three pairs of long chromosomes are similar in length but are distinguishable on the basis of constrictions and satellites. The A-chromosome has a submedian constriction forming a J-shaped chromosome, while the B-chromosome has a subterminal constriction forming a small head, and the E-chromosome has a median constriction giving it a $\mathrm{V}$-shape. The D-chromosome is nearly equal to the B-chromosome in length, and has a somewhat smaller head to which a satellite is attached, while the c-chromosome is somewhat shorter and has a subterminal constriction deeper than that of the D-chromosome. The whole complex bulks somewhat larger than that of leontodontoides, but the types of chromosomes are the same. The size differences within the sets are not the same, however, the most conspicuous difference being in the comparatively greater length of the D-chromosome in aurea. The satellite is also larger and usually attached by a longer thread than in leontodontoides. Each of the chromosomes of aurea is shightly larger than the corresponding chromosome of leontodontoides.

In somatic cells of the hybrid there is little difference between the two parental sets of chromosomes, and it is only rarely that every chromosome can be definitely assigned to one or the other of the parental sets. The A- and B-chromosomes of aurea usually appear a little larger than the rest of the chromosomes, and the larger satellite makes the D-chromosome of aurea distinguishable. The C- and E-chromosomes of the two sets appear so much alike, however, that onty rarely is the slight difference in size evident enough to make distinction possible. In most plates the only visible satellite is that of aurea, but in several instances the small satellite of leontodontoides coukl also be seen although it was always close to the body of the D-chromosome and never separated from it by the usual thread. It therefore seems that the satellite of leontodontoides does not disappear so completely in this hybrid as in the others examined (fig. 14b). 


\section{MEIOSIS}

In meiotic divisions the chromosomes of the two species cannot be distinguished. In contrast to the other hybrids there is great regularity in meiosis. At diakinesis $5_{I I}$ or $4_{I I}+2_{I}$ are seen. In figure $15 a$ one pair of chromosomes appears to be only loosely associated
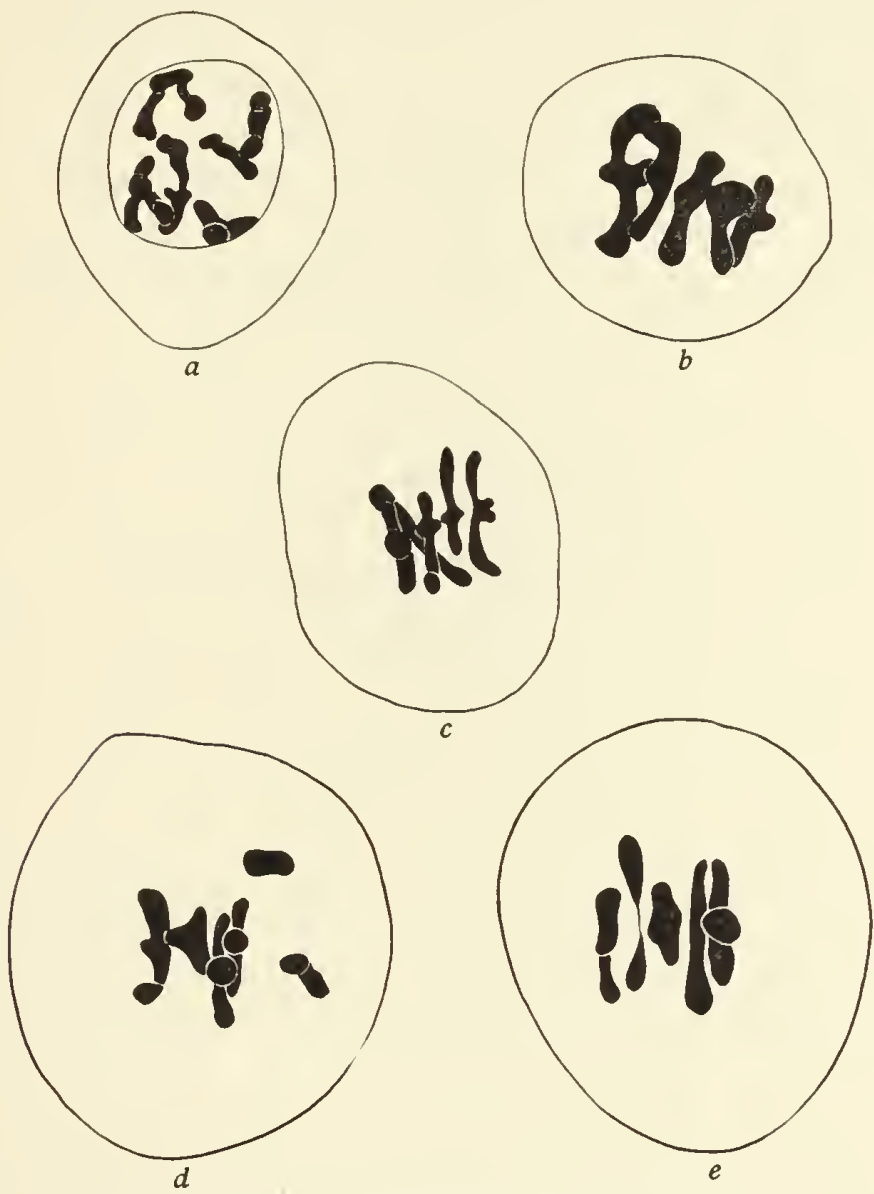

Fig. 15. Meiosis in $\mathrm{F}_{1}$ C. leontodontoides-aurea.

$a$, diakinesis, with five pairs, one pair loosely associated; $b$, and $c, \mathrm{I}-\mathrm{M}$, with five bivalents; $d$, I-M, with four bivalents; $e, I-M$, with four bivalents and one pair loosely conjugated.

while the other four pairs are normally conjugated. The same amount of variation in pairing is found at the first metaphase, $5_{\text {II }}$ being most frequent (figs. $15 b$ and $15 c$ ), but $4_{\text {II }}+2_{I}$ also occur (fig. $15 d$ ) together with many cases of four pairs plus two loosely associated chromo- 
somes (fig. 15e). Rarely two pairs of chromosomes show loose association. Of 53 PMC's in which the type of pairing could be distinguished at diakinesis and I-M, 39 showed $5_{\text {II }}, 12$ showed $4_{\text {II }}+2_{\text {I }}$ (including cells showing one loosely joined pair), and two showed three pairs plus two loosely associated pairs.

As would be expected from such behavior at.I-MI, the I-A and II-A show few irregularities. Occasionally a single chromosome lags, or a pair is late in disjoining at $\mathrm{I}-\mathrm{A}$. One or two chromosomes may rarely be left out of the daughter nuclei at II-T. The tetrads are consequently very regular as compared witl those of the other hybrids. Mieronuclei are oceasionally seen, but microcytes are extremely rare. Dyads are formed as in the other hybrids, but to a very small extent, 2 per cent being the highest number counted, and .5 per cent being the average number in 2158 PMC's.

The number of good stainable pollen grains was exceedingly few in all seven hybrids examined. The range observed was from 1.8 to 3.7 per cent, the most showing 2-3 per cent. Some other factors besides irregularities in chromosome distribution must be operating here to produce inviable pollen grains. The per cent of good grains might lave been higher under more favorable weather conditions, as was found in the case of other hybrids. At any rate, a larger per cent of female gametes must have been capable of functioning since these hybrids set more viable seed than any others upon open pollination when growing next to $C$. leontodontoides.

The contrast between the leontodontoides-aurea hybrid and all other hybrids studied is great. The partial fertility permitting recombinations of parental characters in backerosses of $F_{1}$ is probably directly connected with the more regular meiosis due to the greater amount of normal pairing. This was the only hybrid botlo of whose parents had somatic chromosomes of the same number and types, and of very nearly the same size. The fact that morphological similarity between the somatic chromosomes is followed by conjugation of the chromosomes to a large extent at meiosis would indicate that here morphological similarity of the chromosomes bears some relation to genetic homology. 


\section{RESULT OF CROSSES OF C. LEON'TODONTOIDES WITH}

\section{C. 'TINGI'TANA}

Because of the apparent relationship between $C$. leontodontoides and $C$. aurea, attempts were made during two seasons to obtain hybrids between $C$. leontodontoides and $C$. tingitana, another species with five pairs of chromosomes belonging to the subgenus Catonia and morphologically close to aurea. No hybrids were obtained the first year, and the second year more extensive attempts were made using various plants of both species. However, no hybrids were obtained from crosses involving sixty-two heads.

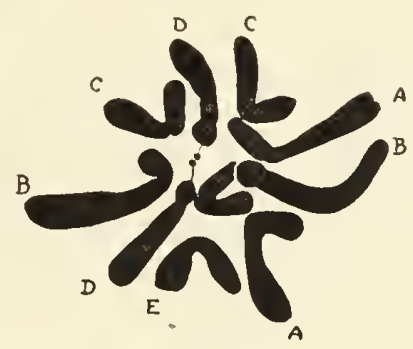

Fig. 16. Somatie metaphase of $C$. tingitana.

The failure to obtain hybrids between leontod ontoides and tingitana does not necessarily mean that the relation between the two species is too distant for the production of such a hybrid. 'The comparative morphology of their somatic chromosomes would suggest, however, that there is a greater difference between the chromosomes of $C$. leontodontoides and $C$. tingitana than between $C$. leontodontoides and $C$. aurea.

All the chromosomes of tingitana are considerably larger than the corresponding chromosomes of leontodontoides and aurea. The difference in size between the chromosomes of tingitana and aurea is much greater than that between those of aurea and leontodontoides. However, the same five types of chromosomes are found in tingitana as in the other two species. The satellited chromosome is somewhat shorter here as compared with the $\mathrm{A}$ - and B-chromosomes than in the other species, being very nearly of the same length as the D-chromosome of aurea. With this exception the size relations within the set 
are close to those found in the other two species, but the total length of the chromosomes, and the total bulk of chromatin, are much greater in tingitana (fig. 16). In figure 17 one chromosome of each type has been drawn from a single somatic cell of each of the three five paired species. Here the similarities and differences in the chromosome complements are evident.

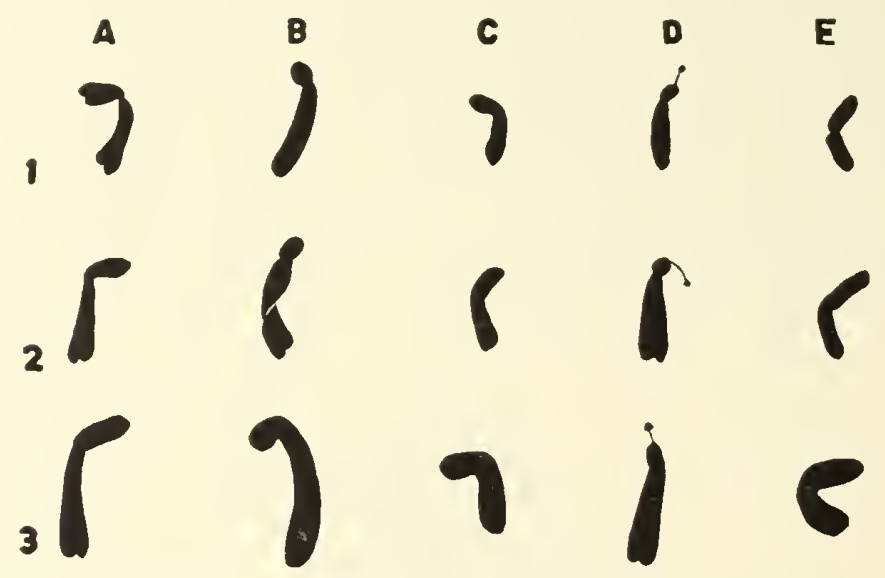

Fig. 17. Somatic chromosomes of (1) C. leontodontoides, (2) C. aurea, (3) C. tingitana. The chromosomes which are similar morphologically are placed under the same letter designations.

\section{Discussion}

Three features observed in these five $\mathrm{F}_{1}$ hybrids deserve consideration, namely, the sharpness of the distinction in morphology between the chromosomes of the parental sets involved, the conjugation of morphologieally distinct chromosomes, and the variable amount of chromosome conjugation. The difference in size between the chromosomes of the paternal and maternal sets is sufficiently great to permit the recognition of practically all the chromosomes as belonging to one genom or the other throughout not only the somatic but also the meiotic divisions in all the hybrids except the $\mathrm{F}_{1}$ leontodontoidesaurea. For this reason the study of the behavior of the parental clromosomes in the meiosis of the hybrids is of particular interest.

The pairing of ehromosomes in these hybrids takes place between chromosonres which are molphologically unlike, and is variable in its extent. This raises the question as to the fundamental nature of the synaptic union, but only indirectly contributes to the solution of this increasingly important problem. 
The large number of careful observations which have been made on the meiotic phases in plants and animals in recent years, together with evidence from genetic and taxonomic studies, has led to the development of the view that when the chromosomes of the two parental sets can be shown to be composed of essentially similar genic material, and are morphologically alike, they will conjugate to form pairs of chromosomes in the prophase of the meiotic division. It is for this reason that all the chromosomes of a pure species normally conjugate to form pairs. Whether genic dissimilarity will cause chromosomes to fail to pair when it has reached a certain point, is not clear from the experimental and observational evidence. Nevertheless, the view of Gates (1928) seems justified, that the conjugation of two chromosomes is evidence of the mutual specific attractions between their similar genes, while lack of conjugation shows dissimilarity in genic constitution. This familiar point of view will be referred to as the "genic attraction" theory.

In the case of species hybrids, different degrees of conjugation between the parental chromosomes have been observed, and it is necessary to explain the differences according to the genic attraction theory if this theory be accepted for the pairing of chromosomes in a pure species. A few species hybrids are known (e.g. Nicotiana alata $\times$ langsdorffii) in which all the chromosomes of one parent pair with all the chromosomes of the other parent. In these eases the chromosomes of the two species are of the same number and of similar morphology. According to the genic attraction theory, we must infer that the basic gemic constitution of the conjugating chromosomes of the two species is similar, and account for divergences in external elaracters leading to specific distinction through gene mutations distributed throughout the respective genoms. The number of gene mutations in such cases is supposed to be within the limits which affect chromosome conjugation.

In species hybrids where the parental species differ in chromosome number and the Drosera type of chromosome conjugation occurs, it would seem that the precise pairing of all the chromosomes of the species of lower chromosome number with an equal number of chromosomes of the species with the high number indicates a similar genic constitution of the conjugating chromosomes. Accordingly, it is possible to suggest that the species with the higher chromosome number has been derived by amphidiploidy from a hybrid between two species with lower chromosome number, one of which or a derivative of 
which, was a parent of the hybrid concerned. Nicotiana tabacum is a species which may have been derived in this way according to Goodspeed and Clausen (1928), who have used the type of pairing found in the hybrids between $N$. tabacum, $N$. sylvestris, and $N$. tomentosa to support this suggestion.

In rare cases (e.g. Crepis biemis $\times$ setosa) it has been found that the chromosomes of one of the parental species conjugate inter se in the $\mathrm{F}_{1}$ hybrid with another species. Such behavior suggests the polyploid nature of the species whose chromosomes exhribit autosyndesis, for the duplication of a chromosome complement followed by only slight alterations within each complement would allow the chromosomes to attract each other when independent of their more genically similar lromologues.

TABLE 2

The Occurrence of a Variable Number of Pairs of Chromosomes in Meiosis in Plants

\begin{tabular}{|c|c|c|c|}
\hline & $\begin{array}{l}\text { Parental } \\
\text { Chromo- } \\
\text { some } \\
\text { Numbers }\end{array}$ & $\begin{array}{l}\text { Number } \\
\text { of pairs } \\
\text { at I-MI }\end{array}$ & Investigator \\
\hline Acgilops ovata $\times$ Triticum vulgare ..... & $14+21$ & $0-3$ & Bleier, 1928. \\
\hline $\begin{array}{l}\text { ovata } \times \text { Triticum monococcum } \\
\text { ventricosa } \times \text { Triticum }\end{array}$ & $14+7$ & $0-5$ & Bleier, 1928. \\
\hline villosum ................ & $14+7$ & $0-4$ & Bleier, 1928. \\
\hline Crepis aspera $\mathrm{x}$ bursifolia.... & $4+4$ & $0-4$ & Babcock and Clausen, 1929 \\
\hline aspcra $\times$ aculcata... & $4+4$ & $3-4$ & Babcock and Clausen, 1929 \\
\hline taraxaeifolia $\mathrm{x}$ tectorum. & $4+4$ & $1-4$ & Babcock and Clausen, 1929 \\
\hline capillaris $\mathrm{x}$ tcctorum...... & $3+4$ & $0-3$ & Hollingshead, 1930a \\
\hline Nicotiana rustica $\times$ tabacum........ & $24+24$ & few & Christoff, 1928 \\
\hline bigelovii $\mathrm{x}$ nudicaulis... & $24+24$ & $4-14$ & Webber, 1927 \\
\hline Papaver atlanticum $\mathrm{x}$ dubium........ & $7+14$ & $1-3$ & Ljungdahl, 1922 \\
\hline somnifcrum $\mathrm{x}$ nudicaule. & $11+7$ & $3-4$ & Yasul, 1927 \\
\hline Polypodium aureum $\mathrm{x}$ vulgarc.. & $34+90$ & $0-30$ & Farmer and Digby, 1910 \\
\hline Solanum nigrum haploid.. & 36 & $3-12$ & Jörgensen, 1928 \\
\hline Triticum dicoccum $\mathrm{x}$ monococcum.... & $14+7$ & $4-7$ & Kihara, 1924 \\
\hline dicoccum $\mathbf{x}$ aegilo poides..... & $14+7$ & $4-7$ & Kihara, 1924 \\
\hline turgidum $\mathrm{x}$ monococcum... & $14+7$ & $3-7$ & Thompson, 1926 \\
\hline spelta $\mathrm{x}$ monococcuin............ & $21+7$ & $0-5$ & Melburn \& Thompson, 1927 \\
\hline vulgarc $x$ sccale cereale..... & $21+7$ & $0-3$ & $\begin{array}{l}\text { Kihara, } 1924 \\
\text { Thompson, } 1926\end{array}$ \\
\hline $\begin{array}{l}\text { Verbascum blattaria x Celsia bugu- } \\
\quad \text { lifolia }\end{array}$ & $15+17$ & $12-15$ & Håkansson, 1926 \\
\hline Viola arvensis $\mathrm{x}$ tricolor............. & $17+13$ & $13-15$ & Clausen, 1922 \\
\hline
\end{tabular}

The table given by Renner $(1929, \mathrm{p}, 107)$ was used as a basis for the list given here. 
Complete failure of all the chromosomes of one set to pair with any of the chromosomes of the other set is not of infrequent occurrence in interspecific hybrids. This oceurs where the chromosomes of the parents are the same in number and norphology, or different. In the first case, the presumption is that the species have become distinct through the accumulation of genic differences of sufficient magnitude to destroy the mutual attraction of homologous chromosomes. Thus in the case of the hybrids between Raphanus and Brassica (Karpechenko 1927) where the parental species belong to different genera, the chromosomes of the two genoms are similar in number and morphology but fail to show any mutual attraction at the heterotypic division. Where the chromosomes of the two genoms which fail to pair differ in number or morphology or both, other processes besides gene mutation have obviously been concerned in the differentiation of the chromosome complements of the species. These processes may be included under the general term "transformations," and will be considered below.

The formation of a variable number of pairs between the chromosomes of the two parental sets, whether they are of the same or of different number and morphology, has been reported as occurring in a number of interspecific hybrids. A list of instances of variable pairing in the case of plant hybrids is given in table 2 . The significance of this type of behavior has been variously interpreted (cf. Farmer and Digby, 1910; Harrison and Doneaster, 1914; and Winge, 1917), but no interpretation in accordance with modern genetic and cytological knowledge has as yet been suggested which seems adequate to account for the occurrence of the variable pairing characteristic of the Crepis hybrids as deseribed above.

The evolutionary processes which it seems reasonable to assume have been largely responsible for the differentiation of the distinct chromosome complements of Crepis species, must also be responsible for the differences between the genoms of the species which cause the formation of a variable number of pairs of chromosomes in meiosis in their hybrids. Hollingshead and Babcock (1930), after a study of the somatic complements of some seventy Crepis species, have pointed out that the differences between the genoms of these species can be accounted for only on the basis that transformational processes have been at work which induce changes in chromosome number and morphology. These transformational processes include mechanical changes in chromosome structure, such as inversion, trans- 
location, deletion, duplication, union, and fragmentation, which have been observed to oceur both under natural conditions and after subjection to high frequeney radiations in Drosophila and Datura.

An illustration of the extent of the change in a chromosome complement which these processes might produce if operating over long periods of time is given in figure 18. Here, through the interference of fragmentation, translocation, inversion, deletion, and duplication, a genom has been evolved which differs in chromosome number, size, and shape, from the original complement. Yet the chromosomes of this "transformed" genom possess segments which are genically similar to segments of the chromosomes of the original complement.

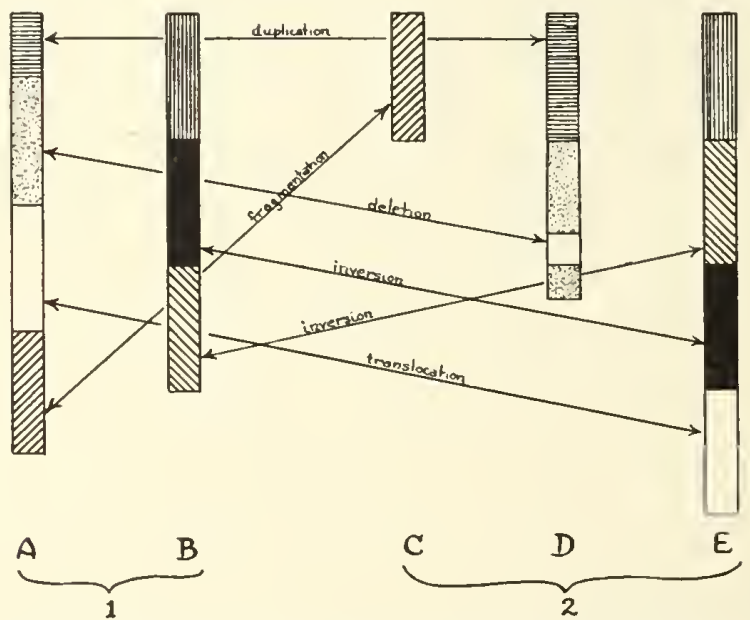

Fig. 18. Diagram showing the possible change in chromosome number and size of a genom brought about through transformational processes. Chromosome segments which are similar in genic constitution in the original and the transformed genom are similarly shaded.

These segments are now borne by chromosomes of different length and morphology. These processes operating under different external conditions over a similar period of time on the sane original chromosone complement would produce transformed genoms of other types, all of which, in common witl the two illustrated, would possess segments of ehromosonles essentially alike in genic constitution. The sinilar genes borne by different transformed genoms must be responsible for the generic characters common to the speeies possessing these different genoms. Deletions and duplications of genes, together with gene mutations taking place concurrently with these transformational processes, and not illustrated in the diagram, may in most eases be responsible for the character differences between the species. 
According to this view, pairing between the chromosomes of complements which are not alike as to number or morphology is due to the residual genie similarity of these ehromosome segments. The larger or more numerous the segments which are genically similar in the case of two chromosomes belonging to different species, the greater is their mutual attraction and the more constant their pairing, while the smaller or fewer the similar segments, the weaker is their attraction and the more variable their pairing, ending in complete failure to pair when the genic similarity is less than a certain minimum. Thus we might explain different extents of chromosome conjugation in the meiotic divisions of the hybrid between two species with the chromosome complements shown in figure 18, upon the assumption that the chromosomes of the last archesporial division enter the resting stage with their orientation with reference to one another a chance one. The segments of chromrosome $A$ of species 1 genically similar to those of ehromosome D of species 2 might then be of sufficient extent to attract this chromosome and permit at least loose conjugation with it, if the two chromosomes are near each other in the early prophase of the heterotypic division. If, however, the two chromosomes are widely separated, the mutual attractions of their genes may be insufficient to permit the chromosomes to conjugate.

The question as to whether or not the chromosomes in mitosis and meiosis are arranged in the spirence stages and the metaplase plates purely by chance, or assume a more definite arrangement dependent upon homology or size, does not seem to have been adequately answered as yet. Kuwada (1929) and his co-workers have shown that the chromosomes in meiosis tend to assume an arrangement characteristic of a like number of magnetized needles of corresponding sizes in a polarized field. Accordingly, the arrangement of chromosomes in both mitosis and meiosis is supposed to be rather definite, and determined by chromosome size and number. Although definite space relations may be the rule, it would seem that in hybrids such as those of Crepis where the chromosomes form a graduated series as to size, there must be several alternative balanced arrangements. The orientation of any one of the large chromosomes in reference to the other chromosomes must also be dependent somewhat on chance, so that proximity in prophase might well be the deciding factor in the conjugation of two chromosomes containing genically similar segments. Cleland (1928) has shown that in Oenothera it is probable that the chromosomes are definitely arranged in the early prophase 
of the meiotic division according to their homologies and parental derivation, but no eytological proof of such definite arrangement in early prophase has been secured in Oenothera or any other organism.

Thus the evidence from the mode of chromosome conjugation in meiosis of interspecific hybrids supports the conclusion drawn from the study of the somatic chromosome complements of sixty-seven species that chromosome transformation has been an important method of differentiation of specific genoms in Crepis.

\section{SUMIIARY}

1. Hybrids between Crepis leontodontoides and species belonging to three subgenera were studied eytologically in both somatic and meiotic phases. C. leontodontoides $(\mathrm{n}=5)$ belongs to the subgenus Eucrepis and the $\mathrm{F}_{1}$ hybrids studied were made with the Eucrepis species tectorum $(\mathrm{n}=4)$, parviflora $(\mathrm{n}=4)$ and capillaris $(\mathrm{n}=3)$; with the Barkhansia species marschalli $(n=4)$, and the Catonia species aurea $(\mathrm{n}=5)$.

2. The chromosomes of the two parental species ean be distinguisled in somatic figures in all the hybrids, although the distinetion is slight in the $\mathrm{F}_{1}$ C. leontodontoides-aurea.

3. The somatic clironosomes of $C$. leontodontoides and aurea are of the same morphological types, but those of aurea are slightly larger. The chromosomes of $C$. tingitana, a Catonia species close to aurea, are of the same number and shape as those of leontodontoides and aurea but are considerably larger. Efforts to secure hybrids between $C$. leontodontoides and tingitana were unsucessful.

4. The satellite disappears from the D-chromosome of leontodontoides in the $\mathrm{F}_{1}$ hybrid with tectorum, parviflora, capillaris, and marschalli, but is sometimes evident close to the D-chromosome in the $\mathrm{F}_{1}$ leontodontoides-aurea.

5. All the chromosomes can be identified as belonging to one or the other of the parental genoms throughout meiotic as well as somatic divisions, in the $\mathrm{F}_{1}$ capillaris-leontodontoiles, and the $\mathbf{F}_{1}$ leontodontoides-tectorum owing to the great size difference between the chromosomes of the two eomplements. In the $\mathrm{F}_{1}$ leontodontoides-parviflora and the $\mathrm{F}_{1}$ leontodontoiles-marschalli all but one or two of the chromosomes of the species with larger and fewer chromosomes can be identified in the meiotic divisions. 
6. The number of bivalents formed in meiosis varied in different PAIC's from complete conjugation between the parental chromosomes to entire absence of conjugation in all hybrids except the $\mathrm{F}_{1}$ leontodontoides-aurea. In this hybrid, the greater extent and regularity of cliromosome conjugation indicates that the morphological similarity of the chromosomes bears some relation to genetic homology. In all other hybrids the pairing is obviously between chromosomes of dissimilar morphology.

7. It is suggested that the variable pairing characteristic of these hybrids is a reflection of the transformational processes presumably responsible for the differentiation of the specific genoms.

\section{LITERATURE CITED}

Babcock, E. B., and Clausen, J.

1929. Meiosis in two species and three hybrids of Crepis and its bearing on taxonomic relationship. Univ. Calif. Publ. Agr. Sci., 2:401-432.

Babcock, E. B., and Navashin, M.

1930. The genus Crepis. Biblio. Genetica, 6:1-90.

BLEIER, H.

1928. Zytologisehe Untersuchungen an seltenen Getreide- und Rübenbastarden.

Verh. V. Interuat. Kong. Vererb. Berlin, 1927, 1:447-452.

Christofi, M.

1928. Cytological studies in the genus Nicotiana. Genetics, 13:233-277.

Ctaudsen, J.

1922. Studies on the collective species Viola tricolor L. II. Botanisk Tidsskrift, 37:363-416.

Cleland, R. E.

1928. The geneties of Oenothera in relation to chromosome behavior with speeial reference to certain lyybrids. Verh. V. Internat. Kong. Vererb, Berlin, 1927, 1:554-567.

Collins, J. L., and Mann, M. C.

1923. Interspecific hybrids in Crepis. II. A preliminary report on the results of hybridizing Crepis setosa Hall. F. with C. capillaris (L) Wallr, and with $C$. biennis L. Geneties, 8:212-232.

FARMER, J. B., and DigBY, E.

1910. On the cytological features exhibited by certain varietal and hybrid ferns. Ann. Bot., 24:191-212.

Gates, R. R.

1928. The relations of cytology to geneties in Oenothera. Verh. V. Internat. Kong. Vererb. Berlin, 1927, 1:749-758.

Goodspeed, T. H., and Clausen, R. E.

1928. Interspecific hybridization in Nicotiana. VIII. The sylvestris-tomentosa-tabacum hybrid triangle and its bearing on the origin of tabacum. Univ. Calif. Publ. Bot., 11:245-256. 
Häkansson, A.

1926. Zur Zytologie ron Celsia und Ferbascum. Lunds Univers. Arsskr., 21:3-47.

HARRISON, J. W. H., and DONCASTER, L.

1914. On hybrids between moths of the geometrid subfamily Bistoninae with an account of the beliavior of the chromosomes in gametogenesis in Lycia (Biston) hertaria, Ithysia (Nyssia) zonaria and in their liybrids. Jour. Genetics, 3:229-248.

HOLLINGSHEAD, I.

1930a. Cytological investigations of lybrids and hybrid derivatives of Crepis capillaris and Crepis tectorum. Univ. Calif. Publ. Agr. Sei., 6:55-94.

1930b. A lethal factor in Crepis effective only in an interspecific hybrid. Geneties, 15:114-141.

Hollingshead, L., and B.tBcock, E. B.

1930. Chromosomes and Pliylogeny in Crepis. Unir. Calif. Publ. Agr. Sei., $6: 1-53$.

JörGENSEN, C. A.

1928. The formation of heteroploid plants in the genus Solanum. Jour. Genetics, 19:133-211.

KARPECHENKO, G. D.

1927. The production of polyploid gametes in hybrids. Hereditas, 9:349-368. KIHARA, H.

1924. Cytologische und genetische Studien bei wichtigen Getreidearten mit besonderer Rücksicht auf das Verhalten der Chromosomen und die Sterilität il den Bastarden. Mem. Coll. Sci. Kyoto Imp. Unir., Ser. B, 1:1-200.

KUHN, E.

1928. Zur Zytologie von Thalictrum. Jalıb. f. wiss. Bot., 68:382-430.

KUWADA, Y.

1929. Model experiments with floating magnets and some theoretical considerations on the problem. Mem. Coll. Sei, Kyoto Imp. Univ., Ser. B, $4: 199-264$.

LJUNGDAHL, H.

1922. Zur Zytologie der Gattung Papaver. Svensk. Bot. Tidskr., 16:103-114.

Meilutra, M. C., and Thompson, W. P.

1927. The cytology of a tetraploid wheat hybrid ( $\mathrm{T}$. spelta $X \mathrm{~T}$. monococeum). Am. Jour. Bot., 14:327-333.

Navashis, M.

1927. Über die Veränderung von Zahl und Form der Chromosomen infolge der Hybridisation. Zeit. f. Zellforsch. u. Mikrosk. Anat., 6:195-233.

1928. "Amphiplastie"-eine ueue karyologische Erscheinung. Verh. V. Int. Kong. Vererb. Berlin, 1927, 2:1148-1152.

RENNER, O.

1929. Artbastarde bei Pflanzen. Handb. der Yererb., 2:1-161.

THompson, W. P'.

1926a. Chromosome behavior in a cross between wheat and rye. Geneties, 11: $317-322$.

1926b. Chromosome behavior in a triploid wheat hybrid. Jour. Geneties, 17: 43-48. 
WEBBER, J. M.

1927. Interspecific hybridization in Nicotiana. Cytological features of two $F_{1}$ hybrids, Bigelovii-nudicaulis and Bigelovii-tabacum, $24 \times 24$ combinations. MS thesis filed in the library of the University of California.

Winge, O.

1917. The chromosomes, their numbers and general importance. Compt. Rend. des. Trav. du Lab. de Carlsberg, 13:131-275.

YASUI, K.

1927. Further studies on genetics and cytology of artifieially raised interspecific hybrids of Papaver. Bot. Mag. Tokyo, 41:235-261. 
